\title{
Evaluation of New Sources of Resistance and Variability for Sugarcane Smut Disease
}

\author{
Raju Singh ${ }^{1,3}$, PriyamVandana ${ }^{1,4}$, Pallavi ${ }^{1}$, M. R. Singh ${ }^{1}$, \\ Sanjeev Kumar ${ }^{2}$, P.K. Singh ${ }^{2}$, J. Singh ${ }^{2}$ and Dinesh Singh ${ }^{1 *}$
}

${ }^{1}$ Division of Crop Protection, ${ }^{2}$ Division of Crop Improvement, ICAR-Indian Institute of Sugarcane Research, Lucknow, India

${ }^{3}$ Chaudhary Charan Singh University, Meerut, India

${ }^{4}$ Department of Molecular \& Cellular Engineering, Sam Higginbottom University of

Agriculture Technology \& Sciences, Allahabad

*Corresponding author

\section{A B S T R A C T}

\begin{tabular}{l} 
K e y w o r d s \\
$\begin{array}{l}\text { Sporisorium } \\
\text { scitamineum, } \\
\text { Variability, Smut } \\
\text { resistance, } \\
\text { Sugarcane }\end{array}$ \\
Article Info \\
$\begin{array}{l}\text { Accepted: } \\
\text { 26 September } 2020 \\
\text { Available Online: } \\
10 \text { October } 2020\end{array}$ \\
\hline
\end{tabular}

Sugarcane (Saccharum spp.) is an important commercial crop, cultivated across the world. Smut disease is one of the major diseases of sugarcane. Severe smut infection affects the sugar recovery as well as yield loss ranging from 10 to $70 \%$. The present study was based on the evaluation of seventy five sugarcane genotypes against smut disease by following seed sett inoculation technique under field condition to screen out the newer sources of resistance as well as susceptible for the development of the smut resistant varieties. Apart from the genotypic evaluation, cultural and morphological variability in sugarcane smut (caused by Sporisorium scitamineum) was also studied to define suitable management strategies. Out of seventy five genotypes screened against the smut disease, thirty eight genotypes viz.,LG 12201, LG 13001, LG 13002, LG 13009, LG 15169, LG 15016, LG 15026, LG 15166, LG 15185, LG 15196, LG 15245, LG 15256, LG 15259, LG 15262, LG15265, LG 15267, LG 16067, LG 16070, LG 16098, LG 16138, LG 16140, LG 16169, LG 16170, LG 16178, LG 16181, LG 16294, LG 17127, LG 17137, LG 17156, CoLk 14201, Co 14034, CoPb 14185, Co 15025, Co 16030, CoPant 16222, CoJ 64, CoLk 7701, Co 7717 and Co 419were rated as resistant (R), fifteen genotypes were found moderately resistant (MR),twelve genotypes were rated as moderately susceptible (MS), six genotypes were rated as susceptible (S) and four genotypes namely LG 17212, LG 17214,LG 17238and CoLk 7701 were rated as highly susceptible (HS). Existence of variability was noticed in the different smut samples collected from different sugarcane varieties/genotypes. Out of the ten isolates tested for cultural and morphological capabilities, each isolate differed strikingly irrespective of the host from where isolated. Isolate A-6 (host genotype LG 17288) of smut was rated as the fastest growing isolate under light condition, attaining $1.2 \mathrm{~cm}, 2.7 \mathrm{~cm}, 3.6 \mathrm{~cm}, 4.3 \mathrm{~cm}$ and $4.5 \mathrm{~cm}$ radial growth at 24h, 48h, 72h, 96h and 120h, respectively followed by isolate A-7. Whereas under dark condition, A-1 (host genotype LG 17151) isolate of Sporisorium scitamineum was rated as fastest growing isolate, attaining $1.7 \mathrm{~cm}, 3.1 \mathrm{~cm}, 4.3$ $\mathrm{cm}$ and $4.5 \mathrm{~cm}$ radial growth at $24 \mathrm{~h}, 48 \mathrm{~h}, 72 \mathrm{~h}$ and $96 \mathrm{~h}$ time intervals respectively. In-vitro study of two different temperature $\left(25^{\circ} \mathrm{C}\right.$ and $\left.35^{\circ} \mathrm{C}\right)$ revealed that $\mathrm{A}-7$ isolate as fastest growing isolate with $1.2 \mathrm{~cm}, 2.0 \mathrm{~cm}, 2.8 \mathrm{~cm}, 3.6 \mathrm{~cm}, 4.3 \mathrm{~cm}$ and $4.5 \mathrm{~cm}$ at $25^{\circ} \mathrm{C}$ and $0.8 \mathrm{~cm}, 1.4 \mathrm{~cm}, 2.3 \mathrm{~cm}, 3.4 \mathrm{~cm}, 3.9$ $\mathrm{cm}$, and $4.5 \mathrm{~cm}$ at $35^{\circ} \mathrm{C}$ in $24 \mathrm{~h}, 48 \mathrm{~h}, 72 \mathrm{~h}, 96 \mathrm{~h}, 120 \mathrm{~h}$ and $144 \mathrm{~h}$, respectively. A-5 was rated as the slowest growing isolate in both the temperatures. Maximum spore length of $1.58 \mu \mathrm{m}$ was recorded with A-1 isolate followed by $1.41 \mu$ mwith A-7 whereas maximum spore width of $0.45 \mu \mathrm{m}$ was recorded with two isolates A-1 and A-7 followed by $0.44 \mu \mathrm{m}$ with A-3 isolate. 


\section{Introduction}

Sugarcane (Saccharum spp.) is an important commercial crop, cultivated across the world. The smut disease of sugarcane caused by Sporisorium scitamineum (Syn: Ustilago scitaminea) is one of the major disease of sugarcane.The first report of the disease incidence came in 1877 from Natal, South Africa (Luthra et al., 1940). Before 1950s, smut disease was not a major disease of sugarcane in Asia but after that the disease spread across the world covering all sugarcane producing countries except Fiji (Ramesh Sundar et al., 2012). Smut infection causes reduction in internodal length, cane thickness and number of millable canes which lastly affects the yield of the crop. Losses due to smut range from $30-40 \%$ in plant crops and even up to $70 \%$ in ratoons (Kirtikar and Verma, 1962; Sandhu et al., 1975). Sucrose content of infected cane is reduced to 3$7 \%$.Presently, sugarcane smutis widespread in all the sugarcane growing states and is a major biotic constraint affecting sugarcane production of the country. The disease caused severe yield loss to sugarcane for long time in Maharashtra and Northern Karnataka regions till the variety Co 740 was under cultivation. The disease was responsible for the elimination of many commercial high yielding varieties and has been the major cause of varietal decline of some superior varieties like Co 419, Co1158, Co 740 and CoS 91269. The impact of the disease is still felt in some parts of Maharashtra, Karnataka and Gujarat. Varietal susceptibility towards the smut hinders the exploitation for multiple ratoon crops. It is found that severity of the disease will be more in the ratoon crop and the modern concept of multiple ratoons cannot be practiced if the variety is susceptible to smut. It was reported that in a susceptible variety, the smut incidence increases tenfold from plant crop to first ratoon crop (James, 1974).Severe smut infection affects the cane yield and sugar recovery. In India, the yield loss due to smut disease is reported up to $50 \%$ (Viswanathan and Rao, 2011).Loss in cane tonnage is recorded due to reduced number of millable canes. It is also witnessed that the smut infection reduced the sugar recovery. In several other countries significant loss in quality and yield was recorded in sugarcane crop due to its smut disease (Ferreira and Comstock, 1989; Magarey and Croft, 1998).

\section{Materials and Methods}

The experiment was conducted atICARIndian Institute of Sugarcane Research, Lucknow, Uttar Pradesh. Freshly collected smutted whips are air dried by keeping under shade and teliospores were collected in butter paper bags and stored in desiccators under anhydrous calcium chloride.

\section{Pathogenicity test}

Pathogenicity test for smut was performed with smut susceptible variety CoLk 7701. The three budded setts of Co 7701 were presoaked in smut teliospore suspension (spore load @ $10^{6}$ spore's $\mathrm{ml}^{-1}$ ) for a period of 30 min and planted in 7 rows of $6 \mathrm{~m}$ length with row to row spacing of $90 \mathrm{~cm}$. The incidence of smut disease was recorded at fortnightly intervals with first record at the time of whip emergence (around 45 days). The total number of smut infected clumps was also recorded and it was found that the variety CoLk 7701 was highly susceptible and hence a good choice for pathogenicity testing.

\section{Evaluation of Genotypes against smut disease of sugarcane}

Three budded setts of all the genotypes were pre-soaked in smut teliospore suspension (spore load@10 $10^{6}$ spores $\mathrm{ml}^{-1}$ ) for a period of 30 minutes by following the technique given 
by Srinivasan (1969) along with the respective checks/standards for resistant and susceptible categories and planted in 7 rows of $6 \mathrm{~m}$ length with row to row spacing of 90 $\mathrm{cm}$. A total of 76 genotypes were subjected for field evaluation and screening.

All the observations were made from the time of whip emergence (around 45 days after sowing) at fortnightly intervals and the number of smut infected clumps was recorded. For the data recording, minimum 20 clumps in each genotype were considered for calculating the percentage infection. The highest number of infected clumps was taken to calculate the percent infection of smut disease. Smut incidence was recorded by counting the number of clumps and varietal reaction was evaluated on the basis of disease rating scale as presented by Rao et al., 1996 with certain modification (Table 1).

\section{Collection of smut whips and spores}

Variability amongst the Sporisorium scitamineum isolates, collected from the experimental field of ICAR-Indian Institute of Sugar Research viz., A-1 (host LG 17151), A2 (host CoS 767), A-3 (host LG 17236), A-4 (host LG17140), A-5 (host LG 17238), A-6 (host LG17288), A-7 (host Co 975), A-8 (host LG 17226), A-9 (host CoLk 7701) and A-10 (host LG 17214), were studied. Smutted whips and spores were collected from these genotypes/varieties during the month of July, 2019. Fully developed smut whips were collected.

Whips were spread out in a tray and maintained in a drying cabinet at room temperature for ten days. Spores were collected from whips by scraping with a plastic knife, and subsequent sieving through nylon net $(1 \mathrm{~mm} \times 1 \mathrm{~mm})$ to remove plant material. Spores were stored in airtight containers at $4{ }^{\circ} \mathrm{C}$ for further experimentation.
Isolation of pathogen (Sporisorium scitamineum)

Smut samples were collected from experimental farm of ICAR- Indian Institute of Sugarcane Research, Lucknow and scraped out from the infected portion in the laboratory under sterile condition. Collected spores were stored in sterilized airtight containers. Spores were placed in Petri plates containing Potato Dextrose Agar medium under sterilized condition and incubated at $27^{\circ} \mathrm{C}$ for 5-6 days.

\section{Radial growth rate of Sporisorium scitamineum in light and dark condition}

Potato dextrose agar medium was used for the study of radial growth of Sporisorium scitamineum under light and dark condition in ten isolates of Sporisorium scitamineum.5 $\mathrm{mm}$ disc of 7 days old culture of smut pathogen was taken and placed in the middle of the Petri plate containing potato dextrose media and incubated at $27^{\circ} \mathrm{C}$. The colony diameter of the smut fungus was recorded after $24 \mathrm{~h}, 48 \mathrm{~h}, 72 \mathrm{~h}, 96 \mathrm{~h} 120 \mathrm{~h}$ and $144 \mathrm{~h}$ time interval.

\section{Radial growth rate of Sporisorium scitamineumat different temperatures}

Smut isolates were cultured on PDA agar plates to study the effect of different temperature conditions on the growth of Sporisorium scitamineum.

Ten isolates of Sporisorium scitamineum were used for the study. $5 \mathrm{~mm}$ disc of 7 days old culture of smut pathogen was placed in the middle of the Petri plate containing potato dextrose media and incubated at two different temperatures $25^{\circ} \mathrm{C}$ and $35^{\circ} \mathrm{C}$. The colony diameter of the fungus was recorded after 24 $\mathrm{h}, 48 \mathrm{~h}, 72 \mathrm{~h}, 96 \mathrm{~h}, 120 \mathrm{~h}, 144 \mathrm{~h}$ and $168 \mathrm{~h}$ interval. 
Morphological characterization of Sporisorium scitamineum

Morphological studies of the isolates ofSporisorium scitamineum were conducted to find out the variability among the isolates of different varieties by comparing their shape and size of the spore. The sugarcane smut pathogen Sporisorium scitamineum (ten isolates) collected from different genotype/varieties were characterized through lacto phenol cotton blue wet mount and examined under compound microscope at 40x and 100x. The fungal morphological characters like teliospores shape, teliospores size (length and width) were also studied (Gaddeyya et al., 2012).

\section{Results and Discussion}

\section{Evaluation of different genotypes against smut of sugarcane}

The study on the evaluation of sugarcane genotypes against smut (Sporisorium scitamineum) was conducted under randomized block design in field conditions during 2019-20 by following seed sett inoculation techniques. Total 75 genotypes were subjected for field experiments. The results (Table 2) revealed that out of 75 genotypes tested against smut of sugarcane, thirty eight genotypes viz., LG 16098, LG 16138, LG 16140, LG 16169, LG 16170, LG 16178, LG 16181, LG 16294, LG 16067, CoJ 64, CoLk 7701, LG 17127, LG 17137, LG 12201, LG 13001, LG 13002, LG 13009, LG 15169, LG 15267, LG 16070, LG 15016, LG 15026, LG 15166, LG 15185, LG 15196, LG 15145, LG 15256, LG 15259, LG 15262, LG 15265, LG 17156, Co 7717, Co 419, CoLk 14201, CoPb 14185, Co 14034, CoPant 16222, Co 16030 and Co 15025 were rated as resistant (R). Fifteen genotypes viz., CoS 767, LG 17140, LG 17141, LG 17201, LG 17197, LG 17143, LG 17185, Co 975, Co 14035,
$\mathrm{CoH}$ 14261, CoPb 14184, CoPant 16221, CoS 16232, CoPb 14211, Co 0238 and CoLk 7701 were rated as moderately resistant (MR).Twelve genotypes viz.,LG 17224, LG 17209, LG 17219, LG 17288, LG 17236, $\mathrm{CoPb}$ 16181, CoLk 14203, CoPb 16212, CoLk 16204, CoLk 16202, CoPant 16223 and CoLk 16203were rated as moderately susceptible (MS). Six genotypes viz., AC 11, LG 17151, LG 17205, LG 17226, CoLk 14204 and $\mathrm{CoPb} 14181$ were rated as susceptible (S). Four genotypes viz., LG 17212, LG 17214, LG 17238 and CoLk 7701 were rated as highly susceptible (HS).The genotypes rated resistant against smut of sugarcane can be exploited for development of smut resistant varieties of sugarcane whereas those rated as highly susceptible can be exploited as susceptible checks for screening against smut of sugarcane. Whip smut of sugarcane ( $U$. scitaminea) is very destructive disease in all sugarcane grown areas of the world. It usually causes losses from germination to maturity of the crop. There was a need to highlight sources of resistant among different clones of sugarcane. Alexander (1987) reported almost similar reaction from India that a large number of clones of $S$. spontaneum and S. officinarum were resistant to smut. High resistance level was also reported to exist in $S$. sinense, $S$. robustum and comparative to $S$. barberi. The low levels of resistance established among $S$. officinarum accessions contrasts with the report of Alexander (1987). The low level of resistance recorded among $S$. officinarum clones, widely grown by farmers in Nigeria, confirms the high incidence of smut on $S$. officinarum varieties reported by Wada et al., (1999). To minimize the loss due to sugarcane smut disease, research on screening of different varieties was done on the basis of disease rating scale as developed by Rao et al., (1996). Micro-environmental conditions are critically important in the development and spread of the pathogen causing smut in 
sugarcane. Some of these can be utilized to form the basis of disease prediction model as well.

\section{Colony growth rate of Sporisorium scitamineum under light condition}

Colony growth rate of 10 isolates were studied in completely randomized block design under light condition in the Laboratory of Crop Protection Division of ICAR-Indian Institute of Sugarcane Research, Lucknow. Out of ten isolates tested against Sporisorium scitamineum (smut of sugarcane), A-7 recorded the fastest growing rate at 24 hours intervals attaining $1.3 \mathrm{~cm}$ diameter (Table 3 ). Whereas A-5 was recorded as the slowest isolate attaining $0.5 \mathrm{~cm}$ colony diameter in the same duration. The growth rates of other isolates were found in between A-7 and A-5 namely, A-1 recorded $0.8 \mathrm{~cm}, \mathrm{~A}-10$ recorded $0.9 \mathrm{~cm}, \mathrm{~A}-8$ recorded $1.0 \mathrm{~cm}, \mathrm{~A}-3$ and A-9 recorded $1.1 \mathrm{~cm}$ whereas A-4 and A-6 recorded $0.9 \mathrm{~cm}$. After 48 hours duration A-6 isolate was found the fastest growing $(2.7 \mathrm{~cm})$ as compared to the slowest growing isolates A-5 $(1.0 \mathrm{~cm})$. The radial growths of other isolates were found to be in the range of 1.0 $\mathrm{cm}$ to $2.7 \mathrm{~cm}$. After 72 hours duration again A-6 recorded fastest growing $(3.6 \mathrm{~cm})$ and A5 was recorded as slowest growing (1.8 $\mathrm{cm})$. The maximum $4.3 \mathrm{~cm}$ radial growth was recorded with 3 isolates viz., A-4, A-6 and A-7 as compare to the minimum $2.8 \mathrm{~cm}$ radial growth of same A-5 isolate at $96 \mathrm{~h}$. After 120 hours incubation, isolates A-2, A-6, A-7, A-8, A-9 and A-10 recorded full petri plate growth as compare to the minimum A-5 $(3.9 \mathrm{~cm})$ followed by A-1 $(4.3 \mathrm{~cm}), \mathrm{A}-3$ and A-4 (4.4 $\mathrm{cm})$. After 144 hours incubation all the isolates attended the full petri plate growth $(4.5 \mathrm{~cm})$ except A-5 isolate. The experimental results revealed that there is variability among the tested 10 isolates. Overall A-6 isolate of Sporisorium scitamineum was rated as the fastest growing isolate attaining $1.2 \mathrm{~cm}, 2.7$ $\mathrm{cm}, 3.6 \mathrm{~cm}, 4.3 \mathrm{~cm}$ and $4.5 \mathrm{~cm}$ radial growth at $24 \mathrm{~h}, 48 \mathrm{~h}, 72 \mathrm{~h}, 96 \mathrm{~h}$ and $120 \mathrm{~h}$, respectively.

\section{Colony growth rate of Sporisorium} scitamineum under dark condition

Colony growth rate of 10 isolates was studied in completely randomized block design under dark condition in the Laboratory of Crop Protection Division of ICAR-Indian Institute of Sugarcane Research, Lucknow. Out of ten isolates tested, A-1 and A-7 were recorded the fastest growing rate at 24 hours attaining 1.7 $\mathrm{cm}$ diameter (Table 3). A-5 was recorded as the slowest growing isolate attaining $1.3 \mathrm{~cm}$ colony diameter at the same duration. The growth rates of other isolates were found in between A-1, A-7 and A-5. A-2, A-6 and A10 recorded $1.6 \mathrm{~cm}, \mathrm{~A}-3 \mathrm{~A}-4$ and A-9 recorded $1.5 \mathrm{~cm}$ whereas $\mathrm{A}-8$ recorded $1.4 \mathrm{~cm}$ in the same duration. After 48 hours duration A-6 and A-10 isolate were found to be the fastest growing $(3.1 \mathrm{~cm})$ as compared to the slow growing isolates A-4 and A-8 $(2.8 \mathrm{~cm})$. The radial growth of other isolates was found in between $3.1 \mathrm{~cm}$ to $2.8 \mathrm{~cm}$. After 72 hours A-1 as recorded fastest growing $(4.3 \mathrm{~cm})$ and A-5 was recorded slowest growing $(3.4 \mathrm{~cm})$ isolate. After 96 hours incubation all the isolates attended the full petri plate growth $(4.5 \mathrm{~cm})$. Again the experimental results revealed that there is variability within the ten tested isolates. Overall A-1 isolate of Sporisorium scitamineum was rated as the fastest growing isolate attaining $1.7 \mathrm{~cm}, 3.1$ $\mathrm{cm}, 4.3 \mathrm{~cm}$ and $4.5 \mathrm{~cm}$ radial growth at $24 \mathrm{~h}$, 48h, 72 hand $96 \mathrm{~h}$ time intervals respectively.

\section{Colony growth rate of Sporisorium scitamineum at $25^{\circ} \mathrm{C}$}

Optimization of physiological condition with special reference to temperature and variability among the 10 isolate of Sporisorium scitamineum were studied under completely randomized block design with 
three replications. The results of experiment conducted at $25^{\circ} \mathrm{C}$ temperature (Table 4) revealed that out of ten isolates tested, isolate A-2 and A-7 recorded fastest growth rate attaining $1.2 \mathrm{~cm}$ maximum radial growth followed by A-3 $(1.1 \mathrm{~cm})$ and A-9 $(1.1 \mathrm{~cm})$ at $24 \mathrm{~h}$ duration. Minimum growth rate of 0.80 $\mathrm{cm}$ was recorded with A-4 and A-5isolates. At the duration of $48 \mathrm{~h}, \mathrm{~A}-7$ recorded as the fastest growing isolate with $2.0 \mathrm{~cm}$ radius as compared to the minimum growth of $1.30 \mathrm{~cm}$ with isolate A-5 followed by A-4 $(1.5 \mathrm{~cm})$. Maximum $2.8 \mathrm{~cm}$ radial growth was recorded with same A-7 isolate followed by A-3 and A-9 isolates $(2.7 \mathrm{~cm})$ at $72 \mathrm{~h}$ interval whereas minimum of $1.9 \mathrm{~cm}$ radial growth was recorded with isolate A-5 at same time duration. Similar trends were also recorded at the duration of $96 \mathrm{~h}$. At the duration of $120 \mathrm{~h}$, isolate A-2 again excels and recorded maximum radial growth of full petri plate $(4.5$ $\mathrm{cm})$ as compared to the other faster growing isolate A-7 with $4.3 \mathrm{~cm}$. At the same time 3.7 $\mathrm{cm}$ minimum radial growth was recorded with the same slow growing isolate A-5. All the isolates recorded full plate petri plate growth at the time duration of $144 \mathrm{~h}$ except A-2 and A-5. As mentioned A-2 recorded full petri plate growth at $120 \mathrm{~h}$ duration whereas A-5 recorded full petri plate growth at $168 \mathrm{~h}$ duration.

\section{Colony growth rate of Sporisorium scitamineum at $35^{\circ} \mathrm{C}$}

Optimization of physiological condition with special reference to temperature and variability among the 10 isolates of Sporisorium scitamineum under completely randomized block design with three replications were worked out. The results of experiment conducted at $35^{\circ} \mathrm{C}$ temperature (Table 4) revealed that out of ten isolates tested, isolate A-7 recorded fastest growth rate attaining $0.8 \mathrm{~cm}$ maximum radial growth at $24 \mathrm{~h}$ duration. Minimum growth rate of 0.2 $\mathrm{cm}$ was recorded with $\mathrm{A}-5$ isolate. At the duration of $48 \mathrm{~h}$, isolate A-7 recorded fastest growing rate with $1.4 \mathrm{~cm}$ radius as compared to the minimum growth of $0.6 \mathrm{~cm}$ with isolate A-5. Maximum $2.3 \mathrm{~cm}$ radial growth was recorded with A-2 isolate followed by A-7 isolate $(2.3 \mathrm{~cm})$ at $72 \mathrm{~h}$ interval whereas minimum of $1.5 \mathrm{~cm}$ radial growth was recorded with isolate A-5 at same time duration. A-1 recorded the maximum radial growth of $3.8 \mathrm{~cm}$ at the duration of $96 \mathrm{~h}$ while minimum growth rate was recorded with A-5 $(2.6 \mathrm{~cm})$. At the duration of $120 \mathrm{~h}$, isolate A$1, \mathrm{~A}-2$ and A-8 showed maximum growth rate $(4.1 \mathrm{~cm})$ and the isolate $\mathrm{A}-3(3.7 \mathrm{~cm})$ showed minimum growth rate. After $144 \mathrm{~h}$, all isolates attended the full petri plate growth (4.5 $\mathrm{cm})$. Overall in-vitro fungal growth study at two different temperatures $\left(25^{\circ} \mathrm{C}\right.$ and $\left.35^{\circ} \mathrm{C}\right)$ revealed that A-7 isolate recorded fastest growth with $1.2 \mathrm{~cm}, 2.0 \mathrm{~cm}, 2.8 \mathrm{~cm}, 3.6 \mathrm{~cm}$, $4.3 \mathrm{~cm}$ and $4.5 \mathrm{~cm}$ at $25^{\circ} \mathrm{C}$ and $0.8 \mathrm{~cm}, 1.4$ $\mathrm{cm}, 2.3 \mathrm{~cm}, 3.4 \mathrm{~cm}, 3.9 \mathrm{~cm}$, and $4.5 \mathrm{~cm}$ at $35^{\circ} \mathrm{C}$ with $24 \mathrm{~h}, 48 \mathrm{~h}, 72 \mathrm{~h}, 96 \mathrm{~h}, 120 \mathrm{~h}$ and $144 \mathrm{~h}$, respectively. Apart from the fastest growing isolate, A-5 was rated as the slowest growing isolate at both the temperatures. It recorded $0.8 \mathrm{~cm}, 1.3 \mathrm{~cm}, 1.9 \mathrm{~cm}, 2.8 \mathrm{~cm}, 3.7 \mathrm{~cm}, 4.2$ $\mathrm{cm}$ and $4.4 \mathrm{~cm}$ at $25^{\circ} \mathrm{C}$ and $0.2 \mathrm{~cm}, 0.6 \mathrm{~cm}$, $1.5 \mathrm{~cm}, 2.6 \mathrm{~cm}, 3.8 \mathrm{~cm}$ and $4.5 \mathrm{~cm}$ at $35^{\circ} \mathrm{C}$ with the time intervals of $24 \mathrm{~h}, 48 \mathrm{~h}, 72 \mathrm{~h}, 96$ h, $120 \mathrm{~h}, 144 \mathrm{~h}$ and $164 \mathrm{~h}$. The comparative physiological study at two different temperatures also proved that $25^{\circ} \mathrm{C}$ temperatures is the optimum temperature for the growth of Sporisorium scitamineum pathogen causing smut disease in sugarcane.

\section{Morphological characterization of Sporisorium scitamineum}

Morphological measurement of 10 test isolates of Sporisorium scitamineum were examined under completely randomized design. Spherical shape of Sporisorium scitamineum was recorded in all the isolates, 
irrespective of the host varieties of sugarcane. Great variation in spore length and width were observed with different test isolates, it may be influenced or derived due to effect of different host varieties of sugarcane and existence of different races in smut fungi. Maximum spore length of $1.58 \mu \mathrm{m}$ was recorded with A-1 isolate of smut followed by $1.41 \mu$ mwith A-7, $1.38 \mu$ m with A-2 and A-3, $1.37 \mu \mathrm{m}$ with A-8, $1.35 \mu \mathrm{m}$ with A-6 (Table 5), whereas minimum spore length of $1.18 \mu \mathrm{m}$ was noticed with A-9 isolate of smut followed by $1.22 \mu \mathrm{m}$ with A-5 and $1.31 \mu \mathrm{m}$ with A4.Sporisorium scitamineum spore width measurement studies revealed maximum spore width of $0.45 \mu \mathrm{m}$ with two isolates A-1 and A-7 followed by $0.44 \mu \mathrm{m}$ with A-3 isolate. Minimum spore width of $0.38 \mu \mathrm{m}$ was recorded with A-9 smut isolate followed by $0.40 \mu \mathrm{m}$ with A-8, $0.42 \mu \mathrm{m}$ with 3 isolates (A-10, A-5 and A-4) and $0.43 \mu \mathrm{m}$ with 2 isolates (A-2 and A-6). Knowledge of existence of races/pathotypes in Sporisorium scitamineum is an important area which is required for the effective deployment of resistant varieties. The existence of physiological specialization has been demonstrated by Alexander and Padmanaban, (1992) and Amire et al., (1982). Classification of races of $U$. scitaminea was based on differences in spore morphology, germination characteristics or pathogenic nature (Sydow, 1924). The pathogen develops systemically throughout the stalk, but teliospores are formed only in peripheral tissues of the whiplike structure. The fungus is capable of mutating and hybridizing in nature in order to produce new virulent pathogenic races (Waller, 1970). Schenck (2003) recorded incidence of smut in one variety (H78-7750), considered to be completely resistant in several seed fields on Maui, indicating the possible emergence of a new race of the smut fungus in Hawaii.

Table.1 Disease rating scale used for categorizing the disease reaction

\begin{tabular}{|c|c|c|}
\hline S. No. & \% Infestation & Category \\
\hline $\mathbf{1}$ & 0 & Resistant (R) \\
\hline $\mathbf{2}$ & $0.1-10$ & Moderately resistant (MR) \\
\hline $\mathbf{3}$ & $10.1-20$ & Moderately susceptible (MS) \\
\hline $\mathbf{4}$ & $20.1-30$ & Susceptible (S) \\
\hline $\mathbf{5}$ & Above 30 & Highly susceptible (HS) \\
\hline
\end{tabular}

Table.2 Evaluation of different genotypes against smut disease of sugarcane under field condition

\begin{tabular}{|c|c|c|c|c|c|c|c|c|}
\hline \multirow[t]{2}{*}{ S.No. } & \multirow[t]{2}{*}{ Genotypes tested } & \multirow{2}{*}{$\begin{array}{l}\text { Total no. } \\
\text { of clumps } \\
\text { observed }\end{array}$} & \multicolumn{4}{|c|}{ No. of Infected clumps } & \multirow{2}{*}{$\begin{array}{l}\text { Maximum } \\
\text { score on out } \\
\text { of four }\end{array}$} & \multirow[t]{2}{*}{ \% Infection } \\
\hline & & & $\begin{array}{c}15^{\text {th }} \\
\text { April }\end{array}$ & $\begin{array}{l}15^{\text {th }} \\
\text { May }\end{array}$ & $\begin{array}{l}15^{\text {th }} \\
\text { June }\end{array}$ & $\begin{array}{l}15^{\text {th }} \\
\text { July }\end{array}$ & & \\
\hline 1 & LG 12201 & 14 & 0 & 0 & 0 & 0 & 0 & 00.00 \\
\hline 2 & LG 13001 & 11 & 0 & 0 & 0 & 0 & 0 & 00.00 \\
\hline 3 & LG 13002 & 12 & 0 & 0 & 0 & 0 & 0 & 00.00 \\
\hline 4 & LG 13009 & 14 & 0 & 0 & 0 & 0 & 0 & 00.00 \\
\hline 5 & LG 15016 & 14 & 0 & 0 & 0 & 0 & 0 & 00.00 \\
\hline 6 & LG 15026 & 11 & 0 & 0 & 0 & 0 & 0 & 00.00 \\
\hline 7 & LG 15166 & 10 & 0 & 0 & 0 & 0 & 0 & 00.00 \\
\hline
\end{tabular}




\begin{tabular}{|c|c|c|c|c|c|c|c|c|}
\hline 8 & LG 15169 & 13 & 0 & 0 & 0 & 0 & 0 & 00.00 \\
\hline 9 & LG 15185 & 07 & 0 & 0 & 0 & 0 & 0 & 00.00 \\
\hline 10 & LG 15196 & 12 & 0 & 0 & 0 & 0 & 0 & 00.00 \\
\hline 11 & LG 15245 & 14 & 0 & 0 & 0 & 0 & 0 & 00.00 \\
\hline 12 & LG 15256 & 14 & 0 & 0 & 0 & 0 & 0 & 00.00 \\
\hline 13 & LG 15259 & 12 & 0 & 0 & 0 & 0 & 0 & 00.00 \\
\hline 14 & LG 15262 & 06 & 0 & 0 & 0 & 0 & 0 & 00.00 \\
\hline 15 & LG 15265 & 06 & 0 & 0 & 0 & 0 & 0 & 00.00 \\
\hline 16 & LG 15266 & 09 & 0 & 0 & 0 & 2 & 2 & 22.22 \\
\hline 17 & LG 15267 & 12 & 0 & 0 & 0 & 0 & 0 & 00.00 \\
\hline 18 & LG 16067 & 15 & 0 & 0 & 0 & 0 & 0 & 00.00 \\
\hline 19 & LG 16070 & 11 & 0 & 0 & 0 & 0 & 0 & 00.00 \\
\hline 20 & LG 16098 & 14 & 0 & 0 & 0 & 0 & 0 & 00.00 \\
\hline 21 & LG 16138 & 19 & 0 & 0 & 0 & 0 & 0 & 00.00 \\
\hline 22 & LG 16140 & 20 & 0 & 0 & 0 & 0 & 0 & 00.00 \\
\hline 23 & LG 16169 & 20 & 0 & 0 & 0 & 0 & 0 & 00.00 \\
\hline 24 & LG 16170 & 18 & 0 & 0 & 0 & 0 & 0 & 00.00 \\
\hline 25 & LG 16178 & 20 & 0 & 0 & 0 & 0 & 0 & 00.00 \\
\hline 26 & LG 16181 & 12 & 0 & 0 & 0 & 0 & 0 & 00.00 \\
\hline 27 & LG 16294 & 16 & 0 & 0 & 0 & 0 & 0 & 00.00 \\
\hline 28 & LG 17127 & 11 & 0 & 0 & 0 & 0 & 0 & 00.00 \\
\hline 29 & LG 17137 & 17 & 0 & 0 & 0 & 0 & 0 & 00.00 \\
\hline 30 & LG 17140 & 20 & 1 & 0 & 1 & 1 & 1 & 05.00 \\
\hline 31 & LG 17141 & 22 & 0 & 0 & 0 & 1 & 1 & 04.54 \\
\hline 32 & LG 17143 & 12 & 0 & 0 & 1 & 1 & 1 & 06.25 \\
\hline 33 & LG 17151 & 15 & 0 & 0 & 0 & 4 & 4 & 26.67 \\
\hline 34 & LG 17156 & 12 & 0 & 0 & 0 & 0 & 0 & 00.00 \\
\hline 35 & LG 17185 & 16 & 0 & 1 & 0 & 0 & 1 & 08.33 \\
\hline 36 & LG 17197 & 19 & 0 & 0 & 0 & 1 & 1 & 05.26 \\
\hline 37 & LG 17201 & 23 & 1 & 0 & 1 & 0 & 1 & 04.34 \\
\hline 38 & LG 17205 & 17 & 0 & 0 & 1 & 5 & 5 & 29.41 \\
\hline 39 & LG 17209 & 21 & 0 & 0 & 1 & 4 & 4 & 19.04 \\
\hline 40 & LG 17212 & 16 & 0 & 0 & 6 & 4 & 6 & 37.50 \\
\hline 41 & LG 17214 & 16 & 0 & 2 & 6 & 3 & 6 & 37.50 \\
\hline 42 & LG 17219 & 18 & 0 & 0 & 0 & 3 & 3 & 16.67 \\
\hline 43 & LG 17224 & 22 & 0 & 1 & 3 & 3 & 3 & 13.63 \\
\hline 44 & LG 17226 & 22 & 0 & 0 & 5 & 4 & 5 & 22.72 \\
\hline 45 & LG 17236 & 26 & 0 & 0 & 1 & 3 & 3 & 11.53 \\
\hline 46 & LG 17238 & 13 & 0 & 0 & 3 & 5 & 5 & 38.48 \\
\hline 47 & LG 17288 & 19 & 0 & 0 & 2 & 2 & 2 & 10.52 \\
\hline 48 & Co 14034 & 13 & 0 & 0 & 0 & 0 & 0 & 00.00 \\
\hline 49 & Co 14035 & 11 & 0 & 1 & 0 & 0 & 1 & 09.09 \\
\hline 50 & $\mathrm{CoPb} 14181$ & 21 & 0 & 5 & 5 & 2 & 5 & 22.72 \\
\hline
\end{tabular}




\begin{tabular}{|l|l|l|l|l|l|l|l|l|}
\hline $\mathbf{5 1}$ & CoPb 14184 & 20 & 0 & 2 & 0 & 2 & 2 & 10.00 \\
\hline $\mathbf{5 2}$ & CoPb 14185 & 21 & 0 & 0 & 0 & 0 & 0 & 00.00 \\
\hline $\mathbf{5 3}$ & CoLk14201 & 21 & 0 & 0 & 0 & 0 & 0 & 00.00 \\
\hline $\mathbf{5 4}$ & CoLk14203 & 26 & 0 & 1 & 3 & 0 & 3 & 11.53 \\
\hline $\mathbf{5 5}$ & CoLk14204 & 21 & 5 & 0 & 0 & 4 & 5 & 23.80 \\
\hline $\mathbf{5 6}$ & CoPb 14211 & 18 & 0 & 0 & 1 & 1 & 1 & 05.56 \\
\hline $\mathbf{5 7}$ & CoH 14261 & 21 & 1 & 1 & 1 & 2 & 2 & 09.52 \\
\hline $\mathbf{5 8}$ & Co 15025 & 12 & 0 & 0 & 0 & 0 & 0 & 00.00 \\
\hline $\mathbf{5 9}$ & Co 16030 & 16 & 0 & 0 & 0 & 0 & 0 & 00.00 \\
\hline $\mathbf{6 0}$ & CoPb 16181 & 29 & 3 & 1 & 2 & 2 & 3 & 10.34 \\
\hline $\mathbf{6 1}$ & CoLk 16202 & 24 & 0 & 1 & 4 & 2 & 4 & 16.67 \\
\hline $\mathbf{6 2}$ & CoLk 16203 & 18 & 0 & 2 & 1 & 3 & 3 & 16.67 \\
\hline $\mathbf{6 3}$ & CoLk 16204 & 21 & 2 & 2 & 3 & 2 & 3 & 14.28 \\
\hline $\mathbf{6 4}$ & CoPb 16212 & 19 & 0 & 0 & 0 & 2 & 2 & 10.52 \\
\hline $\mathbf{6 5}$ & CoPant 16221 & 18 & 0 & 0 & 1 & 1 & 1 & 05.56 \\
\hline $\mathbf{6 6}$ & CoPant 16222 & 14 & 0 & 0 & 0 & 0 & 0 & 00.00 \\
\hline $\mathbf{6 7}$ & CoPant16223 & 24 & 0 & 0 & 3 & 0 & 3 & 12.50 \\
\hline $\mathbf{6 8}$ & CoS 16232 & 22 & 2 & 0 & 0 & 1 & 2 & 09.09 \\
\hline $\mathbf{6 9}$ & Co 419 & 24 & 0 & 0 & 0 & 0 & 0 & 00.00 \\
\hline $\mathbf{7 0}$ & Co 975 & 13 & 0 & 0 & 1 & 0 & 1 & 07.69 \\
\hline $\mathbf{7 1}$ & Co 0238 & 25 & 0 & 0 & 0 & 1 & 1 & 04.00 \\
\hline $\mathbf{7 2}$ & CoJ 64 & 19 & 0 & 0 & 0 & 0 & 0 & 00.00 \\
\hline $\mathbf{7 3}$ & Co 7717 & 25 & 0 & 0 & 0 & 0 & 0 & 00.00 \\
\hline $\mathbf{7 4}$ & CoS 767 & 24 & 1 & 1 & 1 & 0 & 1 & 04.16 \\
\hline $\mathbf{7 5}$ & CoLk 7701* & 20 & 0 & 0 & 0 & 1 & 1 & 36.00 \\
\hline & *: Standard check for smut of sugarcane & & & & & & \\
\hline
\end{tabular}

Table.3 Colony growth rate of Sporisorium scitamineum isolates on PDA media in light and dark condition

\begin{tabular}{|c|c|c|c|c|c|c|c|c|c|c|c|}
\hline \multirow[t]{3}{*}{ S.No. } & \multirow[t]{3}{*}{ Isolate } & \multicolumn{10}{|c|}{ Radial mycelial growth rate of colony in $\mathrm{cm}$} \\
\hline & & \multicolumn{6}{|c|}{ Under light condition } & \multicolumn{4}{|c|}{ Under dark condition } \\
\hline & & $24 \mathrm{~h}$ & $48 \mathrm{~h}$ & $72 \mathrm{~h}$ & 96h & $120 \mathrm{~h}$ & 144h & 24h & $48 \mathrm{~h}$ & $72 \mathrm{~h}$ & $96 \mathrm{~h}$ \\
\hline 1. & A-1 & 0.8 & 2.1 & 3.0 & 3.9 & $4.3(\mathrm{~F})$ & - & 1.7 & 3.1 & 4.3 & $4.5(\mathrm{~F})$ \\
\hline 2. & A-2 & 1.0 & 2.2 & 3.0 & 3.8 & $4.5(\mathrm{~F})$ & - & 1.6 & 2.9 & 4.0 & $4.5(\mathrm{~F})$ \\
\hline 3. & A-3 & 1.1 & 2.2 & 3.2 & 4.2 & $4.4(\mathrm{~F})$ & - & 1.5 & 2.9 & 3.9 & $4.5(\mathrm{~F})$ \\
\hline 4. & A-4 & 1.2 & 2.3 & 3.1 & 4.3 & $4.4(\mathrm{~F})$ & - & 1.5 & 2.8 & 4.0 & $4.5(\mathrm{~F})$ \\
\hline 5. & A-5 & 0.5 & 1.0 & 1.8 & 2.8 & 3.9 & $4.5(\mathrm{~F})$ & 1.3 & 2.9 & 3.4 & $4.5(\mathrm{~F})$ \\
\hline 6. & A-6 & 1.2 & 2.7 & 3.6 & 4.3 & $4.5(\mathrm{~F})$ & - & 1.6 & 3.0 & 3.9 & $4.5(\mathrm{~F})$ \\
\hline 7. & A-7 & 1.3 & 2.5 & 3.4 & 4.3 & $4.5(\mathrm{~F})$ & - & 1.7 & 3.0 & 4.2 & $4.5(\mathrm{~F})$ \\
\hline 8. & A-8 & 0.1 & 1.9 & 2.2 & 3.6 & $4.5(\mathrm{~F})$ & - & 1.4 & 2.8 & 3.8 & $4.5(\mathrm{~F})$ \\
\hline 9. & A-9 & 1.1 & 2.3 & 3. & 4.1 & $4.5(\mathrm{~F})$ & & 1.5 & 3.0 & 3.9 & $4.5(\mathrm{~F})$ \\
\hline 10. & A- 10 & 0.9 & 2.1 & 3. & 4.1 & $4.5(\mathrm{~F})$ & & 1.6 & 3.1 & 4.1 & $4.5(\mathrm{~F})$ \\
\hline
\end{tabular}


Table.4 Colony growth rate of Sporisorium scitamineum isolates on PDA media at $25^{\circ} \mathrm{C}$ and $35^{\circ} \mathrm{C}$

\begin{tabular}{|c|c|c|c|c|c|c|c|c|c|c|c|c|c|c|}
\hline \multirow[t]{3}{*}{ S.No. } & \multirow[t]{3}{*}{ Isolate } & \multicolumn{13}{|c|}{ Radial mycelial growth rate of colony in $\mathrm{cm}$} \\
\hline & & \multicolumn{7}{|c|}{ At $25^{\circ} \mathrm{C}$} & \multicolumn{6}{|c|}{ At $35^{\circ} \mathrm{C}$} \\
\hline & & 24h & $48 \mathrm{~h}$ & 72h & $96 \mathrm{~h}$ & 120h & 144h & $168 \mathrm{~h}$ & 24h & $48 \mathrm{~h}$ & 72h & $96 \mathrm{~h}$ & $120 h$ & 144h \\
\hline 1. & A-1 & 1.0 & 1.7 & 2.4 & 3.3 & 4.1 & $4.5(\mathrm{~F})$ & - & 0.5 & 1.4 & 2.2 & 3.8 & 4.1 & $4.5(\mathrm{~F})$ \\
\hline 2. & A-2 & 1.2 & 1.9 & 2.6 & 3.5 & $4.5(\mathrm{~F})$ & - & - & 0.3 & 1.3 & 2.3 & 3.7 & 4.1 & $4.5(\mathrm{~F})$ \\
\hline 3. & A-3 & 1.1 & 1.8 & 2.7 & 3.5 & 4.2 & $4.5(\mathrm{~F})$ & - & 0.7 & 1.2 & 2.1 & 3.2 & 3.7 & $4.5(\mathrm{~F})$ \\
\hline 4. & A-4 & 0.8 & 1.5 & 2.4 & 3.3 & 4.0 & $4.5(\mathrm{~F})$ & - & 0.5 & 1.1 & 2.0 & 3.0 & 4.0 & $4.5(\mathrm{~F})$ \\
\hline 5. & A-5 & 0.8 & 1.3 & 1.9 & 2.8 & 3.7 & 4.2 & $4.4(\mathrm{~F})$ & 0.2 & 0.6 & 1.5 & 2.6 & 3.8 & $4.5(F)$ \\
\hline 6. & A-6 & 0.9 & 1.7 & 2.6 & 3.5 & 4.2 & $4.5(\mathrm{~F})$ & - & 0.4 & 1.0 & 2.2 & 3.1 & 3.9 & $4.5(\mathrm{~F})$ \\
\hline 7. & A-7 & 1.2 & 2.0 & 2.8 & 3.6 & 4.3 & $4.5(\mathrm{~F})$ & - & 0.8 & 1.4 & 2.3 & 3.4 & 3.9 & $4.5(\mathrm{~F})$ \\
\hline 8. & A-8 & 1.0 & 1.8 & 2.6 & 3.5 & 4.2 & $4.5(\mathrm{~F})$ & - & 0.6 & 1.2 & 2.2 & 3.2 & 4.1 & $4.5(\mathrm{~F})$ \\
\hline 9. & A-9 & 1.1 & 1.9 & 2.7 & 3.6 & 4.1 & $4.5(\mathrm{~F})$ & - & 0.6 & 1.1 & 2.1 & 3.1 & 4.0 & $4.5(\mathrm{~F})$ \\
\hline 10. & A-10 & 1.0 & 1.9 & 2.8 & 3.7 & 4.2 & $4.5(\mathrm{~F})$ & - & 0.5 & 1.1 & 2.1 & 3.0 & 3.9 & $4.5(\mathrm{~F})$ \\
\hline
\end{tabular}

Table.5 Morphological characterization of smut (Sporisorium scitamineum) teliospores

\begin{tabular}{|l|c|c|c|c|}
\hline S. No. & Isolate & Shape & Spore length $(\boldsymbol{\mu m})$ & Spore width $(\boldsymbol{\mu m})$ \\
\hline $\mathbf{1 .}$ & A-1 & Spherical & 1.58 & 0.45 \\
\hline $\mathbf{2 .}$ & A-2 & Spherical & 1.38 & 0.43 \\
\hline $\mathbf{3 .}$ & A-3 & Spherical & 1.38 & 0.44 \\
\hline $\mathbf{4 .}$ & A-4 & Spherical & 1.31 & 0.42 \\
\hline $\mathbf{5 .}$ & A-5 & Spherical & 1.22 & 0.42 \\
\hline $\mathbf{6 .}$ & A-6 & Spherical & 1.35 & 0.43 \\
\hline $\mathbf{7 .}$ & A-7 & Spherical & 1.41 & 0.45 \\
\hline $\mathbf{8 .}$ & A-8 & Spherical & 1.37 & 0.40 \\
\hline $\mathbf{9 .}$ & A-9 & Spherical & 1.18 & 0.38 \\
\hline $\mathbf{1 0}$ & A-10 & Spherical & 1.33 & \multicolumn{2}{|l|}{} \\
\hline
\end{tabular}

\section{References}

Alexander, K. C. and Padmanaban, P. (1992). Smut of sugarcane, In: Plant diseases of international importance, Diseases of sugar, forest, and plantation crops. Mukhopadhyay, A.N., Kumar, J. Chaube, H.S. and Singh, U.S. Englewood Cliffs, USA, Prentice Hall. 4: 1626.

Alexander, K.C. (1987). Durable resistance to red rot and smut diseases of sugarcane Pp. 257-275 in Sugarcane Varietal Improvement Proceedings of the International Symposium on Sugarcane Varietal Improvement (M.K. Naidu, J.V. Screenivasan and M.N. Premachandran, eds). Present Status and Future Thrusts. Held at Sugarcane Breeding Institute Coimbatore to Commemorate its Platinum Jubilee, September 3-7, 1987.

Amire,O. A., Trione, E. J. and Schmitt, R.A. (1982). Characterization of pathogenic races of thesugarcane smut fungus by neutron activation analysis. $J$. Radioanal. Chem.75:195-203.

Ferreira, S. A., and J. C. Comstock. (1989). 
Smut. In Diseases of sugarcane, ed. C. Ricaud, B.T. Egan, A.G. Gillaspie, and C.G.Hughes, 211-229. Amsterdam: Elsevier. USA.

https://doi.org/10.1016/B978-0-44442797-7.50018-1

Gaddeyya, G., Niharika, P. S., Bharathi, P. and Kumar, P. K. R. (2012). Isolation and identification of soil mycoflora in different crop fields at SalurMandal. Adv Appl Sci Res. 3:2020-2026.

James GL (1968). Smut incidence survey in the Rhodesian Lowveld. Proc S Afr Sug Technol Ass42: 172.

Kirtikar and Verma, H.S. (1962).A review on effect of sugarcane disease on yield and juice quality in U.P. Indian Sugar. 12:103-108.

Luthra, J. C., Suttar, A. and Sandhu, S. S. (1940). Experiments on the control of smut of sugarcane. Proceedings in Indian Academy of Sciences, Sec. B. 12:118-128.

Magarey, R.C., and B.J. Croft.(1998). A review on yield losses caused by Australian and selected exotic sugarcane diseases. Proceedings of the Australian Society for Sugar Cane Technology. 20:76-84.

Ramesh Sundar, A., E. Leonard Barnabas, Malathi, P. and Viswanathan, R. (2012). A mini-review on smut disease of sugarcane caused by Sporisorium scitamineum. In Botany, ed. J. Mworia. Rijeka: InTech. ISBN 978-953-510355-4.
Rao, G. P., Triphathi, D. N. P., Upadhaya, U. C., Singh, R. D. R. and Singh, R. R. (1996). New promising red rot and smut resistant sugarcane varieties for eastern Uttar Pardesh. Ind Sugar J. 14:261-263.

Sandhu, S.S., Mehan, V.K., Ram, R.S., Shani, S.S. and Sharma, J.R. (1975).Screening of promising sugarcane varieties for resistance to smut by Ustilago scitaminea Syd.in the Punjab. Indian Sugar.25:423-426.

Schenck, S. (2003). New race of sugarcane smut on Maui. Hawaii, Agriculture Research Center-Pathology Report. 69:1-4.

Srinivasan, K. Y. (1969). Methods for testing the resistance of sugarcane disease 5 . Sugarcane Smut. Sugarcane Pathol. Newsl. 2: 7.

Sydow, H. (1924). Notizen Uber Ushlagineen. Ann. Mycol. 22. pp. 277.

Viswanathan, R. and Rao, G. P. (2011). Disease Scenario and Management of Major Sugarcane Diseases in India. Sugar Tech. 13(4): 336-353.

Wada, A.C., Abo, E.M.,Agboire, S.,Obakin,F.O. and Okunsanya, B. A. (1999). Incidence, Severity and Distribution of Sugarcane Diseases in Nigeria I. Southern Guinea Savannah Zone. Discov. Innov. 11(1/2):33-39.

Waller, J.M. (1970). Sugarcane smut (Sporisorium scitaminea) in Kenya. II. Infection and resistance. Trans British Mycol Soc. 54:405-14.

\section{How to cite this article:}

Raju Singh, PriyamVandana, Pallavi, M. R. Singh, Sanjeev Kumar, P.K. Singh, J. Singh and Dinesh Singh. 2020. Evaluation of New Sources of Resistance and Variability for Sugarcane Smut Disease. Int.J.Curr.Microbiol.App.Sci. 9(10): 3205-3215. doi: https://doi.org/10.20546/ijcmas.2020.910.383 